Poulsen, V. 1966: An occurrence of Lower Palaeozoic rocks within the Precambrian terrain near Sukkertoppen. Rapp. Grønlands geol. Unders. 11, 26 only.

Thorning, L. 1976: Aeromagnetic surveys in southern and central West Greenland between $63^{\circ}$ and $71^{\circ}$ N. Rapp. Grønlands geol. Unders. 80, 61-65.

\title{
A soil sampling programme near a sulphide mineralised norite body, Sitdlisigssanguit nunât, Sukkertoppen district, central West Greenland
}

\section{Jensen and K. Secher}

A detailed geochemical soil sampling programme was carried out during the field season of 1982 on a known sulphide mineralisation. The aim of the programme is to evaluate soil sampling as a prospecting tool in arctic environments. Previous work by Kunzendorf \& Sørensen (1982) on the soil of the nearby Qaqarssuk carbonatite complex has shown promising results for selected elements. The programme also included the collection of rock samples from areas without soil cover. Bedrock is exposed over 5 per cent of the sampling area.

The survey was carried out as a part of GGU's resource evaluation programme in West Greenland (Secher, this report). It also forms part of the current investigation of geochemical methods in mineral exploration in Greenland. A total of 1059 soil samples were collected from two areas, both representing soil-covered contacts between bedrock gneiss and $\mathrm{Cu}-\mathrm{Ni}$ sulphide mineralised norite. In addition a total of 112 rock samples were collected. All samples collected during the programme will be analysed for relevant trace elements.

The sampled areas are situated about $65 \mathrm{~km}$ east of Sukkertoppen, central West Greenland, near the locality Sitdlisigssanguit nunât. The sulphide occurrence was found by the Kryolitselskabet Øresund, who named the locality 'Fossilik'.

The two soil sampling areas were covered with regular grids, constructed with the use of a theodolite and with a point density of $25 \mathrm{~m}$. Areas 1 and 2 are $450 \times 225 \mathrm{~m}$ and $112.5 \times$ $87.5 \mathrm{~m}$, respectively.

In Area 1 the slope varies; there are small ridges and hollows; and the altitude varies from $533 \mathrm{~m}$ to $593 \mathrm{~m}$. Area 2 is situated on a slope dipping $20^{\circ}-30^{\circ}$ to the south-east, with the altitude varying from $530 \mathrm{~m}$ to $572 \mathrm{~m}$.

\section{Geology of the sampling area}

The sampling area is located in Archaean terrain, and was selected to cover the contact zone of an intrusive norite mass in quartzo-feldspathic gneiss. The norite is part of a larger 
body situated in the so-called 'norite' belt (Secher, this report). The sampled areas cover the northern flank of this body where it is dissected by a series of NW-SE faults which also carry Palaeozoic carbonate sediments and Mesozoic lamprophyres. The norite is sulphide mineralised by pyrrhotite, chalcopyrite and pyrite in spots and lenses along the fault zone, and the sulphides occur in up to 10 per cent of the total rock volume.

\section{Soil sampling}

The soil sampling procedure was carried out following the sampling grids with a standard sampling density of $12.5 \mathrm{~m}$. Only in selected profiles, designated $\mathrm{A}-\mathrm{A}^{1}, \mathrm{~B}-\mathrm{B}^{1}, \mathrm{C}-\mathrm{C}^{1}$ and $\mathrm{D}-\mathrm{D}^{1}$, the sampling density was changed to $2.5 \mathrm{~m}$.

\section{Soil development}

Soil development is mainly influenced by moisture content, production of organic matter, texture of the substratum, parent material, time, and stability of the site. In arctic terrains Holowaychuk \& Everett (1972) and Ugolini (1966) have reported that zonal arctic brown soils develop in medium- to well-drained areas. Colloidal organic material is transported down into the underlying mineral soil to produce a dark to pale brown $A_{1}$ horizon, above a brown to yellow-brown $B$ horizon. However, under unfavourable conditions only a thin $A_{1}$ horizon develops (Tedrow, 1970). In poorly to moderately drained areas zonal tundra soils develop. A thin $\mathrm{A}_{1}$ horizon occasionally develops immediately above the $\mathrm{C}_{1}$ or $\mathrm{B}_{\mathrm{g}}$ horizon.

Field observations confirm a similar soil development within the sampling areas with the A horizon as the most common horizon. It is therefore used as the sampling medium. Some soil samples from the B horizon were also collected for comparative studies. In weakly developed soils the samples were collected at the top of the profile.

\section{Overburden}

In any soil sampling survey it is important to distinguish between soil developed on transported overburden or residual material and soil disturbed by solifluction and cryoturbation. Six different types of parent material have been recognized. In the field each type is described in relation to one or several type profiles. These profiles were sampled in great detail on the vertical scale. A preliminary map of distribution of overburden based on type profiles has been drawn (fig. 10).

Till. Soil developed on till is found on ridges and uphill areas. Outcrops are found as isolated spots. The material constitutes unsorted silt and fine-grained sand, with coarser grains, pebbles and a few boulders. The soil is covered by vegetation and is well to medium drained. A and B horizons are usually well developed.

Solifluction soil is the dominant soil type in both areas and is found on slopes. This soil may be difficult to distinguish from till, but it is characterised by buried organic horizons, solifluction lobes, and stone stripes near the sample point. The soil development is disturbed and weak. New A horizons are usually developed on top of the profile. 


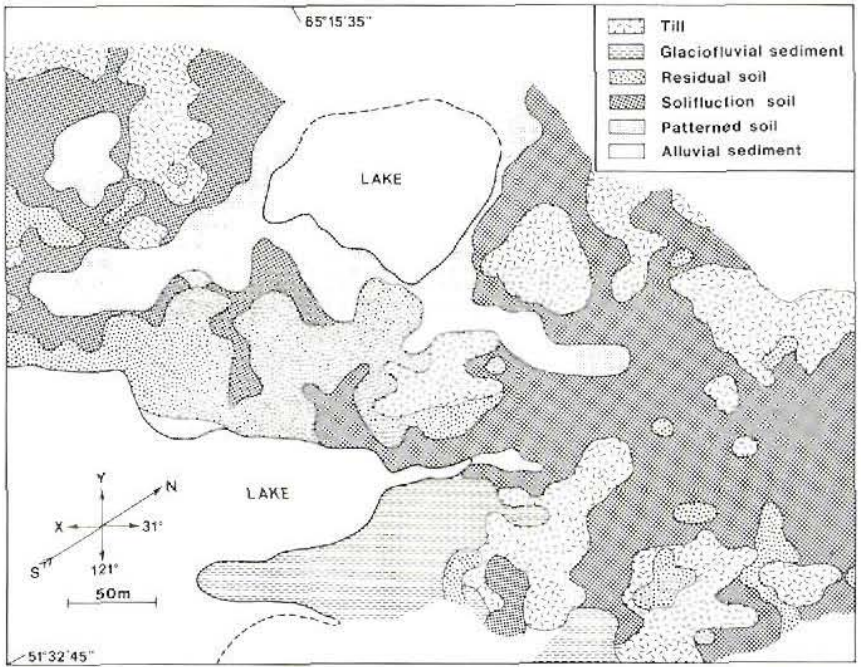

Fig. 10. Map showing distribution of overburden in sampling area 1 at 'Fossilik' in the Sukkertoppen region.

Residual soil is found on weathered norite and is only weakly developed in the vertical profile. Usually only a weak A horizon is developed. The material is made of medium to coarse, angular, residual sand. Vegetation is almost absent and the drainage is usually good. In areas with gossans, the sulphides are completely altered to limonite which colours the soil yellow to red-brown. Vegetation is very scattered and looks as if it is poisoned. Localities with limestone-derived soil have some residual boulders of Palaeozoic fossiliferous limestone and carbonate breccias.

Glaciofluvial sediment is only found in the southern part of area 1. The soil is usually well drained with A and B horizons developed. The material is sandy, sometimes bedded with grain-size increasing downwards. Vegetation is weak and scattered.

Patterned ground is only observed in lows of the topography, and is poorly drained. This type appears mostly as polygon soil, with marked cores and margins. The cores are made of finer material like silt and sand, and the margins are made of pebbles, and even boulders. The A horizon is only developed when vegetation cover is observed.

Alluvial sediment is only observed at one locality and is of very limited extent without soil development.

\section{Conclusions}

Based on the field observations and the overburden map (fig. 10) sorme preliminary conclusions can be drawn:

1) Solifluction and cryoturbation are prevalent in the area, and greatly disturb the soil development.

2) Transported overburden usually shows well developed soil. 
3) Residual soil is pronounced on norite rocks and has weakly developed soil profiles.

4) Soil development is dependent on drainage, vegetation cover and relative age of the parent material.

5) The A horizon is the most common soil horizon observed.

Conclusions regarding the trace element content and distribution of the soil samples, as well as the applicability of the method, will be presented after completion of the analytical programme.

\section{References}

Holowaychuk, J. N. \& Everett, K. R. 1972: Soils of the Tasersiaq area, Greenland. Meddr Grønland 188(6), $37 \mathrm{pp}$.

Kunzendorf, H. \& Sørensen, P. 1982: Reconnaisance geochemical sampling in the Qaqarssuk Carbonatite Complex, West Greenland. Unpubl. intern. Risø report. $10 \mathrm{pp}$.

Tedrow, J. C. F. 1970: Soil investigations in Inglefield land, Greenland. Meddr Grønland 188(3), 32-93.

Ugolini, F. C. 1966: Soils of the Mesters Vig district, Northeast Greenland. Meddr Grønland 176(1), 23 pp.

Institut for almen Ger $\emptyset$ ster Voldgade 10 $D K-1350$ Copenhagen $K$.

\section{A magnetic and electromagnetic investigation of disseminated sulphide mineralisation at 'Fossilik', central West Greenland}

\section{Leif Thorning}

In summer 1982 an experimental geophysical investigation was carried out for one month around an occurrence of disseminated iron-copper sulphides at 'Fossilik', Sukkertoppen. A geochemical sampling programme was undertaken by other geologists.

The object of the geophysical work was to investigate various geophysical methods and instruments in relation to iron-copper sulphide mineralisation in a norite body. For this purpose the Apex Maxmin II and the Geonics EM16/16R were hired from Fenning Environmental Services.

The geophysical activities involved were: (1) magnetic profiling with a Geometrics G856 proton magnetometer; (2) very low frequency (VLF) electromagnetic (EM) measurements using the Geonics EM16 and the American VLF station NAA, $17.8 \mathrm{kHz}$; (3) VLF resistivity measurements using the Geonics EM16R and the same VLF station; (4) horizontal loop EM measurements using the Apex Maxmin II at frequencies $222 \mathrm{~Hz}, 444 \mathrm{~Hz}, 888 \mathrm{~Hz}, 1777 \mathrm{~Hz}$ 